\title{
MOUNDS AND BARROWS AS IMPORTANT ELEMENTS OF CULTURAL LANDSCAPE OF POLAND
}

\author{
AGH University of Science and Technology in Krakow
}

Key words: mounds, barrows, landscape elements, base of mounds and barrows

\begin{abstract}
The tradition of making mounds in the area of Poland goes back to prehistoric times. Mounds had the function as the places of skeleton burials and/or cremation burials as well as places of worship. Later mounds had (among others) the following functions: orientation points, signalization points, landmarks and border points, artificial elevations for development, elements of the landscape in gardens and parks, places of burial, monuments honouring famous people and historic events. Their proper documentation, by their characteristics through graphical description, can be a valuable source on their localization, history and technical shape of the building.

The article presents proposals of a card of scientific documentation of mounds and barrows, using the example of the Krakus Mound. Based on scientific literature, cartographic materials, lists of the Polish Tourist and Sightseeing Society (PTTK) and interviews in the fields, 1111 (including 85 destroyed) mounds and barrows were illustrated on the map, making an open database.
\end{abstract}

\section{KOPCE I KURHANY JAKO ISTOTNE ELEMENTY KRAJOBRAZU KULTUROWEGO POLSKI}

Słowa kluczowe: kopce, kurhany, elementy krajobrazu, baza kopców i kurhanów

\begin{abstract}
Abstrakt
Tradycja sypania kopców i kurhanów na ziemiach polskich sięga czasów prehistorycznych. Kurhany pełniły funkcję mogilną pochówków szkieletowych i ciałopalnych oraz miejsc kultu. Późniejsze kopce spełniały m.in. funkcje: punktów orientacyjnych, sygnalizacyjnych, strażniczych i granicznych, sztucznych wyniosłości terenu pod zabudowę, elementów wystroju ogrodów i parków dworskich, mogilne, pomników ku czci ważnych osobistości i wydarzeń państwowych. Właściwe ich udokumentowanie poprzez charakterystykę opisowo-graficzną może stanowić cenne źródło informacji o lokalizacji, historii oraz stanie technicznym budowli.

W artykule przedstawiono propozycję karty naukowo-dokumentacyjnej kopca lub kurhanu na przykładzie kopca Krakusa. Na podstawie przeprowadzonej kwerendy literatury naukowej, materiałów kartograficznych, wykazów PTTK oraz wywiadów terenowych zilustrowano na mapie lokalizację 1111 kopców i kurhanów (w tym 85 zniszczonych), które stanowią otwartą bazę danych.
\end{abstract}

\section{INTRODUCTION}

There are specific objects of anthropogenic origin made of earth, soil and stones or stones only (common material used nowadays), which are strongly linked to
Slavic culture from its beginning - these are mounds and barrows (in Latin tumulus, pl. tumuli). Already in ancient times (before Slavic tribes arrived in the area of today's Poland), barrows were usually situated on natural elevations of the area. This was also the case in 
19th and 20th century. Mounds and barrows are often related to important historic events and legends (Gill, 2006), known not only to the residents of the regions where they are situated, but also, due to their importance - all over Poland (e.g., the legend about Princess Wanda). Thus, despite the time passing, the mounds and barrows still stand as monuments and symbols, making permanent cultural heritage of the nation, in many cases massively visited by tourists. Mounds in Krakow are examples of well-thought localization, which makes them an integral part of urban landscape. The tradition is also cultivated to make earthen or stone-earthen monuments commemorating persons or events important for the history of the nation.

In fact the name barrows refers to the constructions made in the period from Neolith (megaliths) to early Middle Ages and containing wooden or stone chambers inside the mound, where skeletons or urns were placed. Since prehistoric times the core of the construction usually consisted of a wooden pillar and wicker baskets filled with stones. Such a construction was stable and long-lasting. Unfortunately, widespread lack of interest from local authorities and restoring services in keeping such objects in a proper technical state, as well as the location of these constructions (far from human settlements), thus the lack of proper financial investment, created the situation when many objects lost their previous quality. Limited restoration efforts, lack of the awareness of their historic and educational meaning for the residents of the region, results in further degradation and the loss of the knowledge about their value for culture.

The article presents the results of the first author's query of the set of barrows and mounds based on interviews in the field, archives, archaeological and historical data, tourist guidebooks, etc.

\section{FUNCTIONS OF MOUNDS}

Within the borders of the contemporary Poland, mounds and barrows have been constructed since Neolith, at first in the form of oblong earth-stone prisms, later geometric forms of truncated cones or pyramids (since the first phase of the development of the early Slavic culture) of materials obtained in the vicinity. Their main function was burial of tribal chiefs and rulers. They were equivalent to Egyptian pyramids, constructed to bury sovereigns or important public figures.
Already at early state structures, early Slavs constructed mounds and barrows in a very thorough way, forming a specific system of solar calendar (mounds of Krakus and Wanda, in early Slavic times fulfilled astronomic functions - Banasik and Góral, 2016). With the development of Slavic civilization, over the centuries, functions of mounds were changing.

From safety point of view, in the newly formed state, an important function of the mounds was to use artificially made geometric forms as observation points making the network of objects spatially linked with one another (mainly preserved in Warmia and Masuria), from which the area was observed and looming dangers could be detected and signalled (observation and signalling function).

Additionally, archaeological findings show a considerably well documented group of medieval mounds of totally different functions, such as artificial elevations with complexes of buildings of defensive or residential and defensive character, called settlements (the prototypes of castles or hillforts and later palaces and manors) - Marciniak-Kajzer and Horbacz (1994).

In late Middle Ages a new function of mounds appeared - permanent signs marking borders, often called watchtowers (Kiersnowski, 1960; Klimek, 2016), called scopuli angulares (main points of breaking), more exposed points making (neighbouring) scopuli parietales more densely distributed, or special mounds made at the borders between 3 areas - scopuli aciales (corner points), which marked borders between the land belonging to overlords and Church institutions. Up till now, some border mounds were preserved in Warmia. In Middle Ages they made borders between the lands belonging the Teutonic Order and the Warmia Bishopric. Earthen border cones became especially popular in $16^{\text {th }}$ and $17^{\text {th }}$ century. Despite small size, earthen mounds made clear topographic forms, the purpose of which was unambiguous information about proper borderlines in the field. In case of removal or dislocation of the earthen sign, additionally so-called "border witnesses" were put inside the mounds. As "witnesses" stone forms, tables made of burnt clay, sometimes glazed, were used. They had initials, emblems or other symbols, allowing the identification of the owner (person or institution). Sometimes bottles filled with millet grains and containing sheets of paper with information on the date of forming the border and the names of border villages were put (Duma, 2015). 
In late Middle Ages it became popular to make mounds in central points of gardens belonging to rich people. This type of park earthen forms made distinct elements of the composition of parks and gardens, mainly in the English style (elements of small landscape architecture), fulfilling the role of excellent vantage points (Porada, 2016). Later on, brick-built ice-houses were built into the earthen body of the mound (ice-house in Gryżyny), adding a practical function to them.

During 1st World War the tradition of burial mounds was revived. They were collective graves, a typical example of temporary graveyards (according to German regulations), but in reality they were places of the permanent burial of the fallen soldiers (symbol - monument of the military actions and the brotherhood in battle; so-called brotherly grave).

A numerous group of burial mounds (including stone pyramids and tumuli) were built during the 1st World War in the Western Galicia (Małopolska and Podkarpacie Voivodeships) from January 1916 till November 2018, following the orders of the Austro-Hungarian Ministry of War, by Kriegsgräber Abteilung des K.u.K Militärkommandos Krakau (the Department of War Graves at the Command of the Krakow Garrison). The mounds, with stone or wooden crosses on the top, were located in central points of military cemeteries, located on battlefields or their vicinity. This had metaphysical meaning - a sign of the triumph of life over death, making a unique architectural complex of sepulchral objects (Partridge, 2015). The mounds were designed by famous artists and architects and financed by the Committee for the Management of War Graves in Austria. Some of the graves, including the mounds have been preserved due to the initiative of the Black Cross, which in 1980s and 1990s initiated first revitalization actions. Nowadays the responsibility for the management of these particular monuments belongs to the Council for the Protection of Struggle and Martyrdom Sites (Polish: Rada Ochrony Pamięci Walk i Męczeństwa) and local governments, the task of which is the preservation of cultural heritage and Galician sepulchral objects.

A relatively new group of constructions symbolizing the return to the tradition of making earthen monuments are mounds commemorating and documenting events and personalities important for the Polish history. Usually they were built by local communities to commemorate the actions of national heroes or events forming national identity. Since the time of partitions up till now they have been making a rich set of geotechnical objects, valuable from historical, architectural and cultural point of view. They make valuable sight-seeing objects in Poland, strengthening patriotism among subsequent generations. Yet another group of smaller objects can be added: locally formed elevations of the ground, made of earth, used as pedestals for the elements of small sacral architecture (crosses, shrines) to obtain better visual and aesthetic effects and provide higher significance and monumental character to these objects. Thus, it is common in literature to refer to these monuments as to "crosses/shrines". The role of these objects in forming the historical and patriotic consciousness of Polish people was reflected in the initiative of the Polish Tourist and Sightseeing Society (Polskie Towarzystwo Turystyczno-Krajoznawcze), which introduced programme "The Routes of the Polish Mounds" - Szlakiem Kopców w Polsce (source: www.pttk.pl/przepisy - access August 2018), the main purpose of which was to popularize the interest of historical geotechnical constructions and form historical consciousness of subsequent generations of Poles, by promoting the knowledge, supported by granting special badges.

\section{BARROWS AND MOUNDS IN LEGAL REGULATIONS}

Mounds and barrows make geotechnical objects belonging to the class of stationary historical monuments and, according to art. 6 of the Law on the Protection and Management of Historical Monuments (2003), regardless the state of their preservation should be protected by the conservator-restorer. Historical monuments are managed by the owner or legal custodian and their management requires the following conditions (art. 5 of Law on the Protection and Management of Historical Monuments - 2003):

- archaeological studies and documentation of the monument;

- conservation, restoration and construction works;

- protection and management of the construction and its surrounding so that it is preserved in the best possible state;

- exploitation of the object in the way guaranteeing permanent preservation of its value;

- propagating and promoting knowledge on the monument and its significance for history and culture. 
According to the law, these constructions are classified as monuments, if they are:

- elements of cultural landscape, i.e., natural landscape is transformed by one or more cultural groups and it results in the combination of the elements typical for various overlapping civilizations (Slavic, Celtic, etc.);

- works of architecture and engineering (the Kościuszko Mound in Krakow);

- remains of early Slavic cemeteries (prehistoric mounds, e.g., the Krakus Mound and Wanda Mound in Krakow, 101 barrows in Guciów, etc.);

- designed topographic forms making elements of historic parks and gardens (destroyed Esterka Mound in Krakow);

- places commemorating historic events, especially events of Polish history, or the activities of prominent persons (e.g., the Kościuszko Mound and Piłsudski Mound in Krakow).

\section{MOUNDS AND BARROWS IN HISTORIC TOPOGRAPHIC MAPS}

Over the history the mounds were attributed many various historically and socially important functions. These objects were of monumental character and due to their size and significance for culture, they have been preserved up till now and they make extraordinarily attractive elements of tourist routs of Poland. Small ones, including those of lesser historic importance, but well documented in the preserved archives in the descriptive and graphical form (cartographic works), have chance to appear in the national awareness and make precious source about the development of settlement, including customs in the area of Poland. Usually earthen constructions of this group make heaps formed of earth coming from the closest vicinity, not necessarily the best material for such constructions (not very durable). Mounds were spontaneously constructed by local communities, lacking experience in construction works and knowledge of ground mechanics (especially in those times) and their usefulness in making such investments. In practice this means that originally formed geometric shape of a mound with the elements of small architecture, i.e., crosses, shrines, monuments, obelisks, etc., is getting deformed and diminished by natural phenomena, i.e., erosion, suffusion, blowing winds removing the particles of the ground, as well as the lack of a proper securing of the surface layer of the ground, errors in designing (too big slope) and human activities (tourism on the slopes, mechanical cutting of the slopes, application of improper technologies of securing or only partial their application, ploughing the surface layer of earthen slopes). These facts are confirmed by various preserved historic photographs showing that in the past many mounds were much larger.

In documenting and interpreting the functions of the forgotten mounds and barrows, a very important role belongs to archaeology and surveying. Due to the interdisciplinary studies of archaeological and surveying teams, many of the forgotten and devastated mounds have chance for the ,second life" through detail investigation, documentation, revitalization and efficient advertising.

The importance of mounds, regardless their function, is proved by the traits of their presence in the form of graphical symbols (signatures) on archival topographic maps. They must have been common among artificial topographic forms, because they were included into cartographic information in Prussian, Austrian and Russian maps during partitions (Lewakowski, 1920) and Polish maps, which during the interwar period, were only slightly modified reprints of the maps made during partitions. In the first half of $19^{\text {th }}$ century, topographic anthropogenic forms, as elements of relief, were in Austrian maps illustrated in a very distinct way, in the form of hatching, using Lehman principle (without mathematical justification - Osowski, 1955).

Already at the end of 19 th century the Central Directory of the Measurements in the Prussian State introduced the resolution referring to the requirements of the application of uniform signatures in the topographic and geometric maps and sketches, which significantly simplified „reading” cartographic documents without the necessity to introduce additional conventional signs and limited subjectivity in the interpretation of the cartographer in the process of graphical definition of the object on the map. According to these directives on maps in scale 1:25 000, graphic signature was given only to the mounds fulfilling the function of border points (symbol attributed to the group of the division lines - table 1, position 1a), which was continued on Austrian maps (table 1 - positions: $\mathrm{b}$ and $\mathrm{f}$ ) in scale 1:75000 in the first half of 20th century (Lewakowski, 1920) and their Polish reprints in scale 1:25 000 and 
Table 1. Examples of graphic signatures (point and contour) of mounds and barrows on archived topographic maps

Tabela 1. Przykłady sygnatur graficznych (punktowych i konturowych) kopców i kurhanów na archiwalnych mapach topograficznych

\begin{tabular}{|c|c|c|c|c|c|}
\hline 昰 & $\begin{array}{c}\text { Type of map } \\
\text { Year of publication } \\
\text { Rodzaj mapy } \\
\text { Rok publikacji }\end{array}$ & $\begin{array}{c}\text { Signature } \\
\text { Sygnatura }\end{array}$ & $\begin{array}{l}\text { Scale } \\
\text { Skala }\end{array}$ & $\begin{array}{l}\text { Class } \\
\text { Grupa }\end{array}$ & $\begin{array}{l}\text { Source } \\
\text { Źródło }\end{array}$ \\
\hline $\mathbf{a}$ & $\begin{array}{l}\text { Topographic } \\
\text { Maps Sketches } \\
\text { Mapy topograficzne } \\
\text { Plany } \\
1879\end{array}$ & & $1: 25000$ & $\begin{array}{l}\text { Division Lines } \\
\text { Linie podziałów }\end{array}$ & $\begin{array}{l}\text { Central Directory of } \\
\text { Measurements in the Prussian } \\
\text { State Centralne Dyrektorium } \\
\text { Pomiarów w Państwie Pruskim } \\
1879\end{array}$ \\
\hline b & $\begin{array}{l}\text { Detail Maps } \\
\text { Mapy szczegółowe } \\
1920\end{array}$ & & $\begin{array}{c}1: 75000 \\
\text { (Austrian) }\end{array}$ & $\begin{array}{l}\text { Granice } \\
\text { Borders }\end{array}$ & Lewakowski R., (1920) \\
\hline c & $\begin{array}{l}\text { Topographic Maps } \\
\text { Mapy topograficzne } \\
1922\end{array}$ & & $\begin{array}{c}1: 50000 \\
1: 100000\end{array}$ & - & $\begin{array}{l}\text { Znaki topograficzne map } \\
\text { polskich w podziatce } \\
\text { 1:50.000 i } 1: 100.000 \text {. Instytut } \\
\text { Wojskowo-Geograficzny. } \\
\text { Warszawa } 1922\end{array}$ \\
\hline d & $\begin{array}{l}\text { Maps } \\
\text { Mapy }\end{array}$ & & 1:100 000 & $\begin{array}{l}\text { Embankments and } \\
\text { Trenches } \\
\text { Nasypy i rowy }\end{array}$ & Hełm-Pirgo M., (1928) \\
\hline e & $\begin{array}{l}\text { Sketches } \\
\text { Plany }\end{array}$ & & $\begin{array}{l}1: 20000 \\
1: 25000\end{array}$ & - & \\
\hline \multirow[t]{8}{*}{ f } & \multirow{8}{*}{$\begin{array}{l}\text { Topographic Maps } \\
\text { Mapy topograficzne } \\
1925\end{array}$} & \multirow{2}{*}{ C } & $1: 25000$ & \multirow{2}{*}{$\begin{array}{l}\text { Border Marks } \\
\text { (Austrian Maps) } \\
\text { Znaki graniczne } \\
\text { (mapy austriackie) }\end{array}$} & \multirow{8}{*}{$\begin{array}{l}\text { Zestawienie znaków } \\
\text { topograficznych } \\
\text { map austriackich, niemieckich } \\
\text { i rosyjskich } \\
\text { Wojskowy Instytut } \\
\text { Geograficzny } 1925\end{array}$} \\
\hline & & & $1: 75000$ & & \\
\hline & & & $\begin{array}{c}1: 25000 \\
\text { (Messtischblatt) }\end{array}$ & \multirow{3}{*}{$\begin{array}{l}\text { Trenches and } \\
\text { Embankments } \\
\text { (German Maps) } \\
\text { Rowy i nasypy } \\
\text { (mapy niemieckie) }\end{array}$} & \\
\hline & & & $1: 100000$ & & \\
\hline & & & $1: 100000^{*}$ & & \\
\hline & & \multirow{3}{*}{$n^{+2}$} & $1: 42000$ & \multirow{3}{*}{$\begin{array}{l}\text { Trenches and } \\
\text { Embankments } \\
\text { (Russian Maps) } \\
\text { Rowy i nasypy } \\
\text { (mapy rosyjskie) }\end{array}$} & \\
\hline & & & 1:84000 & & \\
\hline & & & $1: 126000$ & & \\
\hline
\end{tabular}


Table 1 cont.

\begin{tabular}{|c|c|c|c|c|c|}
\hline 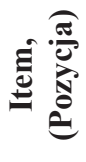 & $\begin{array}{c}\text { Type of map } \\
\text { Year of publication } \\
\text { Rodzaj mapy } \\
\text { Rok publikacji }\end{array}$ & $\begin{array}{l}\text { Signature } \\
\text { Sygnatura }\end{array}$ & $\begin{array}{l}\text { Scale } \\
\text { Skala }\end{array}$ & $\begin{array}{l}\text { Class } \\
\text { Grupa }\end{array}$ & $\begin{array}{l}\text { Source } \\
\text { Źródlo }\end{array}$ \\
\hline g & $\begin{array}{l}\text { Mapy topograficzne } \\
\text { Topographic Maps } \\
1961\end{array}$ & & \multirow{2}{*}{$\begin{array}{c}\text { 1:25000 } \\
\text { 1:50 } 000 \\
\text { 1:100 } 00 \\
\\
\text { Notice: } \\
\text { 5- height } \\
\text { of the mound } \\
\text { in [m] }\end{array}$} & $\begin{array}{l}\text { Field Objects } \\
\text { Przedmioty } \\
\text { terenowe } \\
\text { a - impossible to } \\
\text { be presented in the } \\
\text { map scale } \\
\text { a - nie dający } \\
\text { się przedstawić } \\
\text { w skali mapy; } \\
\text { b - in the map } \\
\text { scale } \\
\text { b- w skali mapy }\end{array}$ & $\begin{array}{l}\text { Znaki umowne dla map } \\
\text { topograficznych w skali } \\
1: 25 \text { 000, } 1: 50000,1: 100000 . \\
\text { Ministerstwo Obrony } \\
\text { Narodowej (Szt. Gen. 271/61). } \\
\text { Zarząd Topograficzny Sztabu } \\
\text { Generalnego } 1961\end{array}$ \\
\hline $\mathbf{h}$ & $\begin{array}{l}\text { Topographic Maps } \\
\text { Mapy topograficzne } \\
1966 / 1986\end{array}$ & & & $\begin{array}{l}\text { impossible to be } \\
\text { presented in the } \\
\text { map scale } \\
\text { nie dający się } \\
\text { przedstawić } \\
\text { w skali mapy; } \\
\text { - w skali mapy } \\
\text { In the map scale }\end{array}$ & $\begin{array}{l}\text { Znaki umowne } \\
\text { map topograficznych } \\
\text { Ministerstwo Obrony } \\
\text { Narodowej - Sztab Generalny } \\
\text { (Szt. Gen. 1348/88). Warszawa } \\
1988\end{array}$ \\
\hline
\end{tabular}

* Mapy Królestwa Kongresowego i dawnych Ziem Litewskich [Maps of the Congress Kingdom and Old Lithuanian Territory]

Table 2. Examples of point marks of small architecture elements based on mounds and barrows

Tabela 2. Przykłady znaków punktowych elementów małej architektury posadowionych na kopcach lub kurhanach

\begin{tabular}{|c|c|c|c|}
\hline 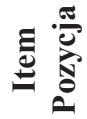 & $\begin{array}{l}\text { Signature } \\
\text { Sygnatura }\end{array}$ & $\begin{array}{l}\text { Explanation } \\
\text { Objaśnienie }\end{array}$ & $\begin{array}{l}\text { Source } \\
\text { Źródło }\end{array}$ \\
\hline $\mathbf{a}$ & & $\begin{array}{l}\text { - stone or wooden cross, } \\
\text { - shrine, statue of a saint }\end{array}$ & $\begin{array}{l}\text { Centralne Dyrektorium Pomiarów w Państwie Pruskim } \\
\text { (German document) [1] }\end{array}$ \\
\hline b & & $\begin{array}{l}\text { - shrine (class: buildings and objects) } \\
\text { - religious statue } \\
\text { - cross }\end{array}$ & $\begin{array}{l}\text { Zestawienie znaków topograficznych } \\
\text { map austriackich, niemieckich i rosyjskich } \\
\text { Wojskowy Instytut Geograficzny } 1925 \\
\text { (refers to Austrian maps in scales: } \\
1: 25000 \text { and } 1: 75000 \text { ) }\end{array}$ \\
\hline c & 土 & - religious statue & $\begin{array}{l}\text { ibidem (refers to German maps in scales: } \\
1: 25000-\text { left and 1:100 000- right) }\end{array}$ \\
\hline
\end{tabular}


Table 2 cont.

\begin{tabular}{|c|c|c|c|}
\hline d & 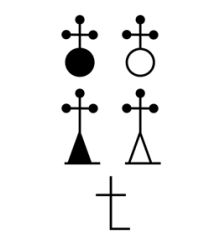 & $\begin{array}{l}\text { - shrine (class: buildings and objects) } \\
\text { - religious statue } \\
\text { - cross }\end{array}$ & $\begin{array}{l}\text { ibidem (refers to Russian maps in scales: } \\
1: 21000,1: 42000 \text { and } 1: 84000 \text { ) }\end{array}$ \\
\hline $\mathbf{e}$ & $\begin{array}{l}2 \text { y } 98,7 \\
3 \text { - 99,3 }\end{array}$ & $\begin{array}{l}\text { - triangulation point on the mound } \\
\text { - polygony point on the mound }\end{array}$ & \multirow{2}{*}{$\begin{array}{l}\text { Conventional signs - patterns of writing and abbrevia- } \\
\text { tions for topographic maps in scale 1:25 000, 1:50 000, } \\
\text { 1:100 } 000 \text { (wzór 1951). } \\
\text { Ministerstwo Obrony Narodowej Warszawa } 1956 \\
\text { Conventional signs - pattern for topographic maps } \\
\text { in scale 1:25 000, 1:50 000, 1:100 000. } \\
\text { Ministerstwo Obrony Narodowej (Szt. Gen. 271/61). } \\
\text { Zarząd Topograficzny Sztabu Generalnego 1961 }\end{array}$} \\
\hline $\mathbf{f}$ & $\begin{array}{l}+ \\
\frac{1}{n} \text { br.mog. } \\
\frac{D}{\Delta} \\
+\end{array}$ & $\begin{array}{l}\text { - shrine } \\
\text { - statue or sculpture } \\
\text { - brotherly grave } \\
\text { - monument, statue, sculpture higher } \\
\text { than } 1 \mathrm{~m} \\
\text { - single (war) grave } \\
\text { - cross or religious figure }\end{array}$ & \\
\hline
\end{tabular}

1:75 000 (Wojskowy Instytut Geograficzny [Military Geographic Institute] 1925).

There is a large group of mounds from the times of partitions and WWI, the tops of which contain elements of small architecture, i.e., sacral statues, crosses, shrines and obelisks. The way of their graphical interpretation (regardless the state of the origin of the cartographic centre) depended on the size of earth cone and accepted scale of the cartographic document. Thus only large mounds, possible to be presented in the scale of the topographic map, making bases for the monuments were presented in detail, i.e. in two signs - by the point signature (a statue or cross, shrine, monument, or mound on a collective grave, a so-called brotherly grave - examples of point signs are included in table 2) with a symbol of the scarp of geometry projecting a real shape of the construction in the field (contour symbols were presented in the maps published during the patricians - see table 1 - positions: c-e, inter-war period position: f and after the second world war - in Polish maps - positions: g-h). Thus in case of small earthen cones (regardless the type of form on the top), correct identification of the object and decision if the signature (point sign) in the map presents only a sacral object $\leftrightarrow$ cross on the plinth, or on the mound, should be veri- fied individually in the field (an example can be a small mound dedicated to Józef Piłsudski in Neple, with a big wooden cross on the top).

\section{FIRST INVENTORY QUERY OF MOUNDS AND BARROWS - STATISTICS}

The main impulse to make a map of the location of mounds and barrows, was an extensive documentation by Grzegorz Gill of 2006: „Kopce w krajobrazie kulturowym Polski" [Mounds in the Cultural Landscape of Poland], where a rich set of information on the most popular preserved mounds made on the Polish soil over two thousand years is documented in an descriptive and photographic way. Based on Gill G. (2006), field interviews carried out by the author, analysis of many scientific articles on history and archaeology, referring to the documentation of this kind of constructions, cartographic documentation (including cartographic historical documents), first graphical documents illustrating localization of mounds and barrows of high historical cultural and ethnographic values - figure 1 . One can assume that this database makes an important resource that will sometimes be significantly upgraded by the data coming from subsequent stage of the query of var- 


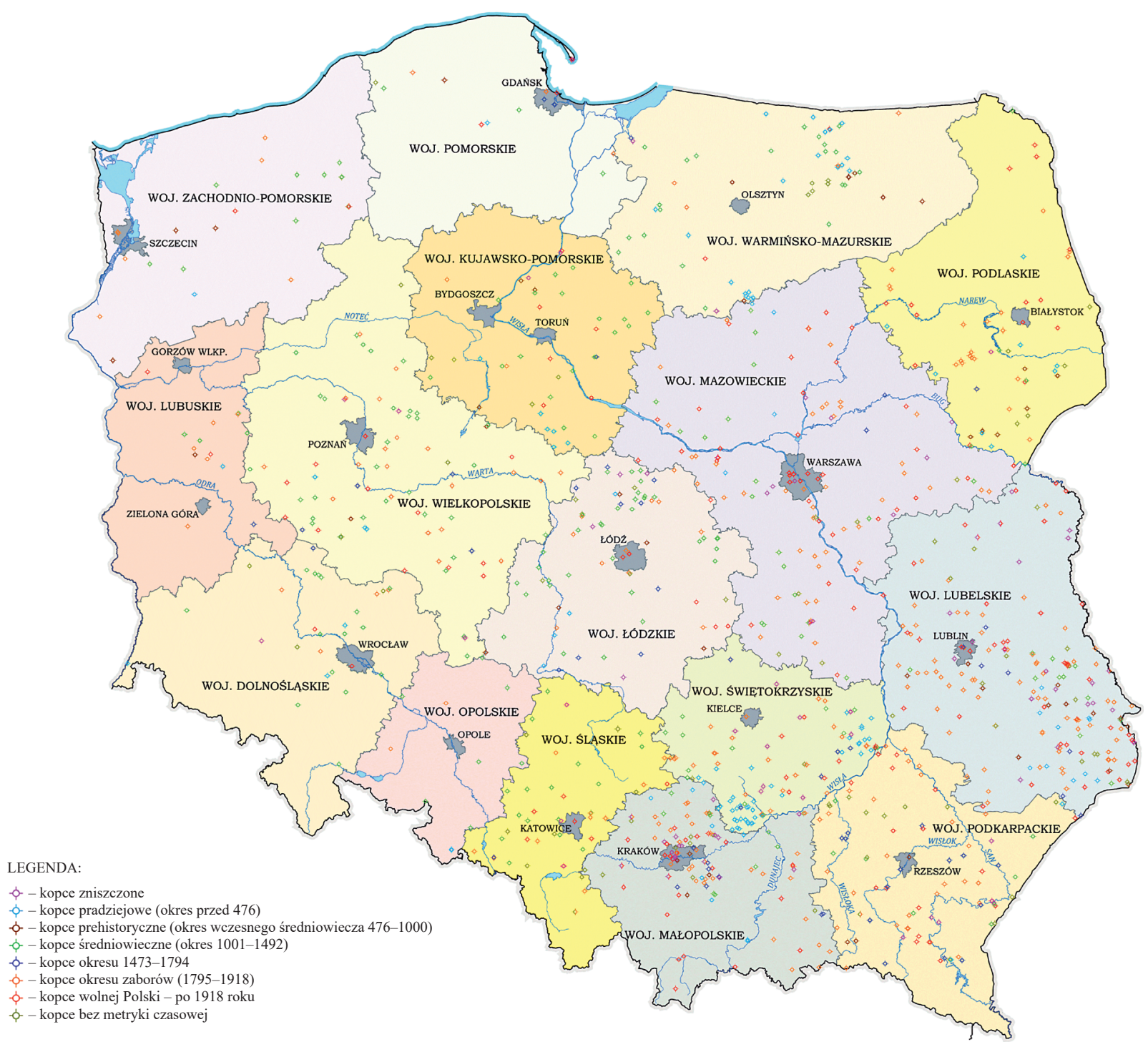

Fig. 1. Location of barrows and mounds in Poland - first query (Authors' own work)

Ryc. 1. Lokalizacja kurhanów i kopców w Polsce - pierwsza kwerenda (opracowanie własne)

Destroyed mounds

Pre-historical mounds (before 476)

Pre-historical mounds (early Middle Ages 476-1000)

Medieval mounds (1001-1492)

Mounds of 1493-1794

Mounds of the times of partitions (1795-1918)

Mounds of independent Poland - after 1918

Mounds with no time records

ious preserved archive materials and studies carried out in Poland by various scientific and research institutes. This stimulates the development of modern surveying and inventory technologies applied in archaeology, geology and surveying, which are constantly improved and applied in the detection, identification and documentation of this type of constructions forgotten and transformed by nature and people. Being aware that many of them have not been documented so far, due to their bad technical state, the degree of transformations due to atmospheric and anthropogenic factors not allowing their identification (localization, range and function). Additionally, the lack of documentation confirming the functioning of such an object in the past 
Table 3. Quantitative statistics according to the adopted time classification

Tabela 3. Statystyka ilościowa według przyjętej klasyfikacji czasowej

\begin{tabular}{|c|c|c|}
\hline $\begin{array}{l}\text { Group } \\
\text { Grupa }\end{array}$ & $\begin{array}{l}\text { The time interval } \\
\text { Przedzial czasowy }\end{array}$ & $\begin{array}{c}\text { Quantity } \\
\text { Liczebność }\end{array}$ \\
\hline 0 & $\begin{array}{l}\text { Destroyed } \\
\text { Zniszczone }\end{array}$ & 85 \\
\hline 1 & $\begin{array}{l}\text { Ancient before } 476 \\
\text { Starożytne przed } 476\end{array}$ & 116 \\
\hline 2 & $\begin{array}{l}\text { Early Middle Ages 476-1000 } \\
\text { Wczesne średniowiecze 476-1000 }\end{array}$ & 47 \\
\hline 3 & $\begin{array}{l}\text { Middle Ages 1001-1492 } \\
\text { Średniowieczne 1001-1492 }\end{array}$ & 226 \\
\hline 4 & 1493-1771 & 59 \\
\hline 5 & $\begin{array}{l}\text { Partition period } 1772-1918 \\
\text { Okres zaborów } 1772-1918\end{array}$ & 303 \\
\hline 6 & $\begin{array}{l}\text { Free Poland after } 1918 \\
\text { Wolna Polska - po } 1918\end{array}$ & 190 \\
\hline \multirow[t]{2}{*}{7} & $\begin{array}{l}\text { Mounds without time record } \\
\text { Kopce bez metryki czasowej }\end{array}$ & 85 \\
\hline & $\begin{array}{l}\text { Total (including destroyed) } \\
\text { Łącznie budowli } \\
\text { (w tym zniszczone) }\end{array}$ & $1111^{(1)}$ \\
\hline
\end{tabular}

(1) - full list of the mounds and barrows with their administrative units, due to its size, will be put in the monograph „Kurhany i kopce w krajobrazie kulturowym Krakowa i Polski" [Barrows and mounds in the cultural landscape of Krakow and Poland] (in preparation)

(testimomienies), makes the process of the verification of hypotheses and proper recognition of the constructions or their restoration in case of high archaeological, historic, educational and social value. Today it is difficult to estimate the total number of mounds and barrows. The first analysis of such dataset enabled adding 1026 existing objects (identifiable in the field) and 85 destroyed, but historically documented objects, which is shown in figure 1 . The set of 1111 objects was divided in 7 groups according to the accepted time classification (table 3), although according to the author, their number can be doubled. Further interviews in the field will allow future verification of much information collected by the author, but not verified yet, referring to other anthropogenic earthen forms of this type in Poland. Group 7 makes a particular set of anthropogenic objects, which will be probably subdued to further modification. The group includes earth constructions with no formation time attributed, because of the lack of information on the purpose of the construction, available before the time of publishing this article.

\section{PROPOSAL OF THE INFORMATION CARD OF A MOUND OR BARROW}

A large group of mounds and barrows includes well documented objects from archaeological and historical point of view. Usually they are properly secured by restorers or local authorities and communities; thus well preserved from technical and aesthetic point of view. Unfortunately, the localization of mounds often makes the main determinant of their state and condition and tourist popularity. These located within the borders of Polish cities, are usually constantly monitored and subdued to conservation measures and are the objects of interest of local authorities. Many mounds, located in the countryside or forests, far away from human settlement, were forgotten and often degraded. A proper interpretation of archived historic maps, especially rich in height contents (German, Austrian an Russian publications) and historical literature, supported by archaeological activities, can contribute to the discovery and documenting still more objects of this type. Interdisciplinary character of such works, by combining historical knowledge, archaeological and geodetic activities, will allow making the full database documenting all the preserved mounds and barrows in Poland.

Thus, according to the author, a very useful tool for the restoring services, local governments, local historic associations, which more and more often take the role legal custodians, can be all-Polish list of mounds collected in the form of the set of the documentation cards, which paradoxically can protect these objects from being forgotten and fully degraded. A perfect model of such documentation can be register cards of the area threatened by mass movements of earth - system SOPO. Thus it seems necessary to make an information card for each monument, containing the following content:

- history (origin and further development),

- archaeological (documentation of archaeological works - findings),

- surveying (localization, morphometric parameters, detail cartographic documentation, 3D models, regarding elements of small architecture), supplemented by photographic documentation. 
Table 4. An example of a scientific and documentation card of the Krakus Mound (Authors' own work)

Tabela 4. Przykład karty naukowo-dokumentacyjnej dla kopca Krakusa w Krakowie (opracowanie własne)

Scientific and documentary card of the Krakus Mound

Karta naukowo-dokumentacyjna kopca Krakusa

1. Register Number ${ }^{(1)}$

\begin{tabular}{|l|l|}
\hline $\mathbf{1}$ & $\mathbf{2}$ \\
\hline
\end{tabular}$-$\begin{tabular}{|l|l|}
\hline $\mathbf{6}$ & $\mathbf{1}$ \\
\hline
\end{tabular}$-$\begin{tabular}{|l|l|l|}
$\mathbf{0}$ & $\mathbf{1}$ & $\mathbf{1}$ \\
\hline
\end{tabular}

2. Localization of the mound/barrow:

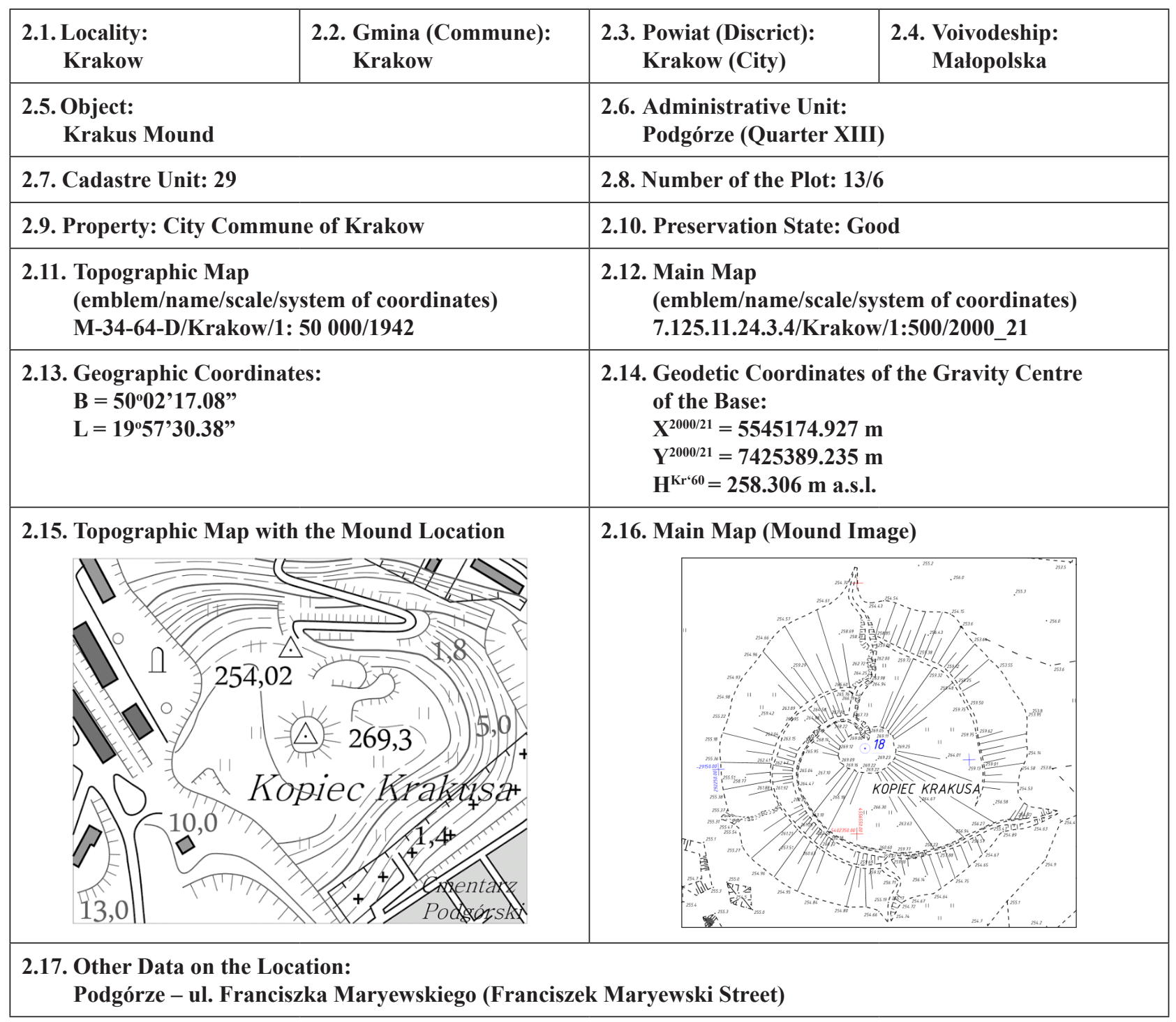

3. Age and Origin of the Mound/Barrow

\begin{tabular}{|l|l|l|}
\hline $\begin{array}{l}\text { 3.1. Date of constructing: } \\
\text { Probably } 7^{\text {th }}-8^{\text {th }} \text { century }\end{array}$ & $\begin{array}{l}\text { 3.2. Source of chronological data: } \\
\text { Gill G., 2006 }\end{array}$ & $\begin{array}{l}\text { 3.3. Function: } \\
\text { Religious-Ritual }\end{array}$ \\
\hline $\begin{array}{l}\text { 3.4. Listing in the Register of Historic } \\
\text { Monuments of Krakow: (YES/ } / \mathbb{\Theta})^{(2)}\end{array}$ & $\begin{array}{l}\text { 3.5. Number in the Register of Historic Monuments } \\
\text { of Krakow: } \\
\text { A-955 11/10/1933 (according to the state of July 2013) }\end{array}$ \\
\hline
\end{tabular}


4. Photographic Documentation

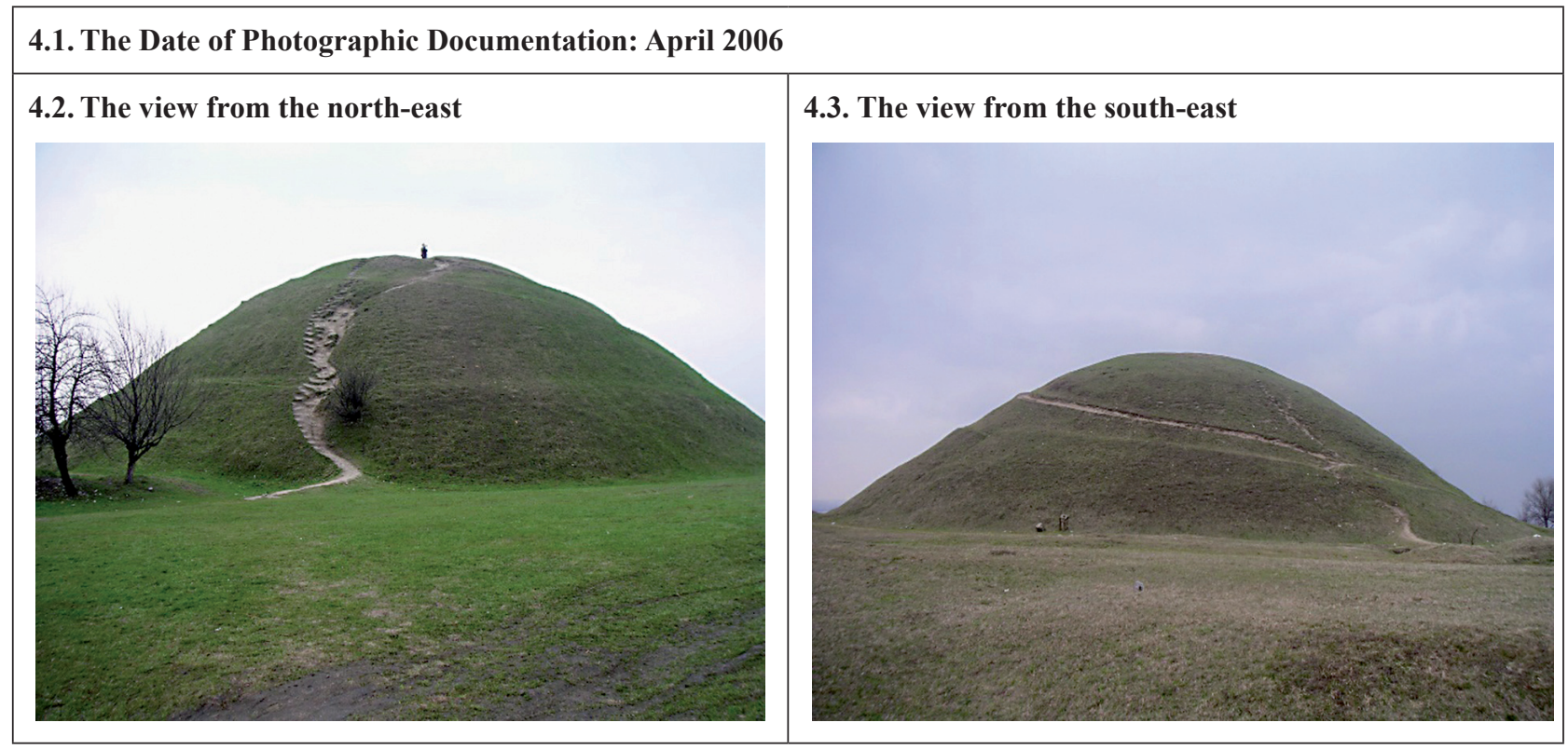

5. Archaeological and geological studies (YES/NO) $)^{(2)}$

\subsection{Date of the studies:} 1934-1937
5.2. The kind of the carried out studies: archaeological in the form of deep cone digging

6. Morphometric Parameters of the Mound/Barrow

\begin{tabular}{|c|c|c|}
\hline $\begin{array}{l}\text { 6.2. The area of the base } \\
1.8 \mathrm{~m}^{2}\end{array}$ & $\begin{array}{l}\text { 6.2. Maximal/minimal diameter } \\
\text { of the base: } \\
68.27 \mathrm{~m} / 59.26 \mathrm{~m}\end{array}$ & $\begin{array}{l}\text { 6.3. Volume: } \\
22076 \mathrm{~m}^{3}\end{array}$ \\
\hline $\begin{array}{l}\text { 6.4. Absolute height of the base: } \\
H_{\max }=253.40 \mathrm{~m} \text { a.s.l. }\left(\mathrm{Kr}^{\prime}{ }^{60}\right) \\
H_{\min }=255.21 \mathrm{~m} \text { a.s.l. }\left(\mathrm{Kr}{ }^{\prime} 60\right)\end{array}$ & $\begin{array}{l}\text { 6.5. Absolute height of the crone: } \\
H_{\max }=269.23 \mathrm{~m} \text { a.s.l. }\left(\mathrm{Kr}{ }^{\prime} 60\right) \\
H_{\min }=268.90 \mathrm{~m} \text { a.s.l. }\left(\mathrm{Kr}{ }^{\prime}{ }^{60}\right)\end{array}$ & $\begin{array}{l}\text { 6.6. Relative height: } \\
H_{\max }=15.68 \mathrm{~m} \\
H_{\min }=13.69 \mathrm{~m}\end{array}$ \\
\hline $\begin{array}{l}\text { 6.7. Maximal slope: } \\
52.6^{\circ}\end{array}$ & & $\begin{array}{l}\text { 6.8. Elements of small architecture } \\
(\nVdash E S / N O)^{(2)}\end{array}$ \\
\hline \multicolumn{3}{|c|}{ 6.9. Date of marking morphometric parameters (up-dating): April 2006} \\
\hline 6.10. Model 3D (YES/AO) $)^{(2)}$ & & $\begin{array}{l}\text { 6.11. Person (e-mail) and unit making documentation } \\
\text { (addres): } \\
\text { Rafal Gawałkiewicz, Ph.D., eng. } \\
\text { (gawalkie@agh.edu.pl) } \\
\text { AGH-UST in Krakow } \\
\text { Al. Mickiewicza } 30 \\
\text { 30-059 Kraków }\end{array}$ \\
\hline
\end{tabular}


7. The kind and range of instrumental monitoring works (YES/A $\Theta)^{(2)}$

7.1. Measurement Date: April 2006

7.2. Type of measurement: total station, precise levelling, GNSS

7.3. Network of control points (YES/NO) ${ }^{(2)}$

8. Information on landslides (system SOPO)

8.1. Phenomena of earth mass movements (YESTNO) ${ }^{(2)}$

8.2. Date of the recording of a land slide: -

8.3. No. of the landslide card: -

8.4. Description of damage: -

8.5. Date of revitalization (renovation) works: $2^{\text {nd }}$ half of 2013 (by MEGA-BUD)

The proposal of the information card (scientific and documentary) of a mound and barrow, using the Krakus Mound in Krakow was presented in table 4. - identifier accepted following „Wykaz identyfikatorów i nazw jednostek podziału terytorialnego kraju” [List of identifiers of 1 st January 2010 of the Central Statistical Office]

- cross out the unnecessary option

Explanation of point 1:

\begin{tabular}{|c|c|c|c|c|c|c|c|c|c|c|c|c|}
\hline 1 & 2 & - & 6 & 1 & - & 0 & 1 & 1 & - & $\mathbf{0}$ & O & 1 \\
\hline \multicolumn{2}{|c|}{ 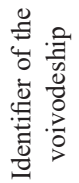 } & \multicolumn{3}{|c|}{ 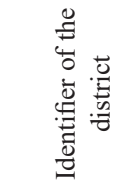 } & \multicolumn{4}{|c|}{ 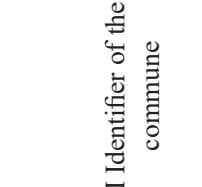 } & \multicolumn{4}{|c|}{ 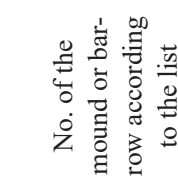 } \\
\hline
\end{tabular}

\section{CONCLUSIONS}

In the Polish society, the tradition of constructing commemoration mounds is very strong. It is still vivid in $21^{\text {st }}$ century, which is manifested in many initiatives represented by specially formed for this purpose societies and committees, organized to have further earth monuments - patriotic symbols - constructed. An example of planned activities are the following mounds:

- Defenders of Lviv in Wrocław,

- Independence (100-anniversary or re-gaining independence) in Zator,

- John Paul II in Krakow-Łagiewniki,

- Glory to the Cavalry and Artillery in Wolica Śniatycka,

- „Soil of the Polish People” in Kończewice,

The construction of each of these mounds is an activity requiring great labour and financial means, not only during the construction works, but also during the exploitation (preventive measures securing the con-

struction, routine repairing and major renovations). It seems reasonable not to build new mounds, especially while facing the lack of funds for the maintenance of the existing mounds and barrows (the Kościuszko Mound in Krakow).

The engagement of many regional research institutes, scientific and research institutes, local enthusiasts of history and ethnography of the region, create the possibility to make rich theme databases. Connecting local datasets provides information on the groups and types of the objects under the restorer's care and phenomena in the study area. Making particular database of mounds and barrows perfectly fits present educational and didactic and historical trends of growing social consciousness and the will to learn about the natural and civilizational values (cultural, religious and engineering artefacts) of the place. Thus more and more often can we find valuable publications by local enthusiasts and research units where the inventory is done and directed very narrowly e.g. in terms of nature (inventory of small water bodies), 
or ethnography and religion (list of historic shrines and crosses at the road). Detail documentation of mounds and barrows in the form of a systematic database - descriptive, photographic and graphic (cartographic), will make a valuable source of information for:

- restorers (protection and restoration of constructions),

- owners or managers of the areas, where mounds and barrows are localized (range of duties within the maintenance of this type of constructions),

- local authorities (plans of raising the attractiveness of the region by making tourist educational, didactic and historic routes),

- tourists interested in history and ethnography of the visited region.

Information presented in this article makes the outline of the initial stage of archival works the author has been carrying out for several years.

The article was financed from the grant "badania statutowe" 16.16.150.545.

\section{REFERENCES}

Centralne Dyrektorium Pomiarów w Państwie Pruskim z 20 grudnia 1879 z uwzględnieniem poprawek wprowadzonych uchwałami z 16 grudnia 1882 i 12 grudnia 1884 roku.

Duma P. (2015). Tajne świadki graniczne w Europie Środkowej od XVI do XIX w. - problem stabo zbadany, Kwartalnik Historii Kultury Materialnej, vol. 63, no. 1, pp. 79-91.

Gill G. (2006). Kopce w krajobrazie kulturowym Polski, Małopolskie Stowarzyszenie Miłośników Tradycji Mazurka Dąbrowskiego w Krakowie, wyd. 2 uzup. Wydawnictwo DjaF, Kraków.

Banasik P., Góral W. (2016). Kopiec Krakusa a zachód Stońca $w$ dniu przesilenia letniego - aspekty astronomiczno-archeologiczne, „Materiały Archeologiczne”, vol. 41, pp. 303-314.

Hełm-Pirgo M. (1928). Kartoznawstwo $i$ wojskowe wyzyskanie terenu. Wydawnictwo Zakładu Narodowego im. Ossolińskich. Lwów - Warszawa - Kraków.
Hlebionek-Woźniak A., Hlebionek M. (2011). Ustalenia w sprawie stosowania jednolitych sygnatur na mapach topograficznych $i$ geometrycznych, planach i szkicach na podstawie uchwaty Centralnego Dyrektorium Pomiarów w Państwie Pruskim z 20 grudnia 1879 z uwzględnieniem poprawek wprowadzonych uchwałami z 16 grudnia 1882 i 12 grudnia 1884 roku (accessed: 04.2018).

Kiersnowski R. (1960). Znaki graniczne w Polsce Średniowiecznej. Archeologia Polski, vol. 5, no. 2, pp. 257-289.

Klimek R. (2016). Ślady średniowiecznej granicy Warmii między Reszlem a Świętą Lipką. Studia Geohistorica. Rocznik Historyczno-Geograficzny, no. 4, pp. 38-50.

Lewakowski J. (1920). Klucz znaków przyjętych dla map austriackich 1:75000 i 1:200000, pruskich 1:100000 i 1:200000, rosyjskich 1:84000 i 1:126000. Terenoznawstwo i Kartografia Wojskowa. Nakładem Księgarni J. Czerneckiego. Warszawa-Kraków.

Marciniak-Kajzer A., Horbacz T.J. (1994). Gruszczyce, st. 1, gm. Błaszki, woj. Sieradzkie, AZP 69-42/-. Informator Archeologiczny: badania, no. 28, pp. 93-94.

Znaki umowne dla map topograficznych $w$ skali 1:25 000, 1:50 000, 1:100 000. (1961). Ministerstwo Obrony Narodowej. Zarząd Topograficzny Sztabu Generalnego 271/61. Warszawa.

Osowski F. (1955). Dokumentacja Geograficzna. Stan pokrycia obszaru Polski materiałami kartograficznymi. Polska Akademia Nauk - Instytut Geografii, no. 10. Warszawa.

Partridge A. (2015). W stulecie hekatomby. Cmentarze wojenne z lat 1914-1918 w dawnej Galicji Zachodniej jako unikatowy zespót sepulkralny. Dzieje, twórcy, symbolika, stan zachowania, problemy ochrony. Pamięć Wielkiej Wojny, Ochrona Zabytków, no. 1, pp. 95-129.

Porada K. (2016). Kopce w krajobrazie Krakowa i okolic. Topiarius - Studia Krajobrazowe, Wydanie monograficzne Krajobraz Polski. Cudze chwalicie. Ochrona i kształtowanie rodzimego krajobrazu - tom 1. Rzeszów, pp. 121-130.

Ustawa o ochronie zabytków i opiece nad zabytkami z dnia 23 lipca 2003 roku (Dz.U. 2017.0.2187).

Zestawienie znaków topograficznych map austriackich, niemieckich i rosyjskich (1925). Druk i wydanie Wojskowy Instytut Geograficzny. Warszawa.

Znaki topograficzne map polskich $w$ podziatce 1:50.000 i 1:100.000 (1922). Nakładem Instytutu Wojskowo-Geograficznego. Warszawa. 